\title{
Preliminary experience with transperitoneal single incision laparoscopic surgery adrenalectomy
}

\author{
Andrzej Budzyński', Michał Pędziwiatr' ${ }^{1}$, Maciej Matłok ${ }^{1}$, Alicja Hubalewska-Dydejczyk², Marta Matyja², \\ Monika Buziak-Bereza ${ }^{2}$ \\ $1^{\text {nd }}$ Department of Surgery, Jagiellonian University Medical College, Krakow, Poland \\ 2Department of Endocrinology, Jagiellonian University Medical College, Krakow, Poland
}

Videosurgery and other miniinvasive techniques 2010; 5 (3): 87-92 DOI: 10.5114/wiitm.2010.16418

\begin{abstract}
Introduction: The aim of contemporary medicine is not only a successful course of the operation, leading to improvement of the patient's health status, but also its satisfactory cosmetic effect. Single incision laparoscopic surgery (SILS) is a new advance wherein laparoscopy is carried out through a small incision hidden in the umbilicus. It therefore combines these two major objectives allowing for a good clinical result after a practically scarless operation.

Aim: To present the preliminary experience in using the SILS method for treatment of patients with adrenal gland tumours.

Material and methods: In March 2010 we performed 7 SILS adrenalectomies in patients treated in our department. Preoperative examinations confirmed hormonal activity in 6 of them and in 1 patient increase in the size of the tumour (by $12 \mathrm{~mm}$ ) was the indication for the operation. All procedures were performed using the lateral transperitoneal approach where after creation of a small incision in the umbilicus the SILS port was placed. The operation was then conducted using a technique similar to standard multiport adrenalectomy. In 1 patient it was necessary to place 2 additional trocars in order to properly mobilize the spleen.

Results: We did not observe any difference in the operative time versus multiport laparoscopy. No postoperative complications occurred.

Conclusion: SILS adrenalectomy is a safe procedure but requires a lot of experience in laparoscopic adrenalectomy. If any problem occurs during the procedure it is always possible to place additional trocars and convert the operation to multiport laparoscopy. To date the only evidenced advantage of the new procedure is its better cosmetic result.
\end{abstract}

Key words: minimally invasive surgery, laparoscopy, adrenal glands

\section{Introduction}

Nowadays, laparoscopic adrenalectomy is the gold standard in the management of adrenal gland tumours qualified for surgical treatment. There are multiple reports univocally proving the superiority of this technique over the classical approach [1-7]. Recently, initial reports on the possibility of using single incision laparoscopic surgery (SILS) in these cases have emerged. SILS is a surgical procedure performed using a single incision in the umbilicus. This reduces the trauma and therefore decreases the need for analgesics in the postoperative period and greatly improves the postoperative cosmetic effect. There are multiple publications regarding this method that unambiguously support its use. However, to date they have regarded mainly cholecystectomies [8-12]. 


\section{Aim}

The aim of this study is to present the initial experience with SILS application in adrenal gland tumour resection.

\section{Material and methods \\ Patients}

From February until May 2010, 7 patients treated in the $2^{\text {nd }}$ Department of Surgery of the Medical College of Jagiellonian University were qualified for SILS adrenalectomy. The group consisted of 5 females and 2 males. Mean age in the group was 54.4 years (31-68 years) (Table I). Four left and 3 right adrenalectomies were performed using the SILS method. Presence of an adrenal gland tumour confirmed by imaging was the indication for surgery. In 6 patients the tumour was hormonally active and in 1 patient it was not. The rationale for surgery in this patient was increase in the tumour size from 23 to $35 \mathrm{~mm}$ during the 1-year observation, based on imaging (Table II).

Patients signed informed consent to the proposed treatment and were qualified for adrenalectomy by the SILS method.

Table I. Study group characteristics

\begin{tabular}{|lccc|}
\hline Gender & $\begin{array}{c}\text { Number } \\
\text { of patients }(n)\end{array}$ & $\begin{array}{c}\text { Mean age } \\
\text { [years] }\end{array}$ & $\begin{array}{c}\text { Age intervals } \\
\text { [years] }\end{array}$ \\
\hline Female & 5 & 51.8 & $31-59$ \\
\hline Male & 2 & 61 & $54-68$ \\
\hline Total & 7 & 54.4 & $31-68$ \\
\hline
\end{tabular}

\section{Methods}

Prospective analysis of the material consisted of such parameters as:

- length of procedure,

- frequency of complications,

- blood loss in the perioperative period,

- need for conversion to multiport laparoscopy,

- length of hospital stay.

Procedures were performed using transperitoneal access with the patient lying on the right side for left adrenalectomy and on the left side for right adrenalectomy (Figure 1). The body position was stabilized using gel pads. After making a $3 \mathrm{~cm}$ longitudinal incision in the umbilicus, a SILS port (Covidien) was introduced and the pneumoperitoneum was generated. A $10 \mathrm{~mm}$ laparoscope with $30^{\circ}$ angle optics was introduced through the port. No other pathological changes were found during the inspection; therefore other instruments were introduced. In the case of left adrenal gland operation, tissue preparation started with mobilization of the splenic flexure of the colon (Figure 2). Next, the phrenicosplenic ligament was dissected, mobilizing the spleen and the pancreatic tail, which enabled visualization of the left adrenal gland (Figure 3). Following dissection to free the left suprarenal vein and its outlet to the left renal vein, it was clipped with a medium size clip using a $5 \mathrm{~mm}$ clip applier (Figure. 3). Superior, middle and inferior suprarenal arteries were provided for consecutively. The adrenal gland was dissected from surrounding tissues using a harmonic scalpel (Figure 4). Mobilization of the liver's right lobe was necessary during the right adrenalectomy. The right suprarenal vein near

Table II. Characteristics of patients subjected to SILS adrenalectomy

\begin{tabular}{|lccccccc|}
\hline Patient & Gender & Age & Site & Tumour size $[\mathrm{mm}]$ & Hormonal activity & Conversion \\
\hline A.S. & F & 54 & Left & 29 & Yes (Cushing's syndrome) & No \\
\hline T.K & F & 56 & Left & 44 & Yes (Cushing's syndrome) & No \\
\hline K.G & M & 54 & Right & 20 & Yes (Conn's syndrome) & Yes & No \\
\hline A.G & F & 31 & Right & 46 & Yes (pheochromocytoma) & No \\
\hline E.F & F & 57 & Left & 35 & Yes (pheochromocytoma) & No \\
\hline M.K & M & 68 & Right & 36 & & No \\
\hline E.R & F & 59 & Left & 20 & Yes (Cushing's syndrome) & No \\
\hline
\end{tabular}

* Two additional trocars introduced 


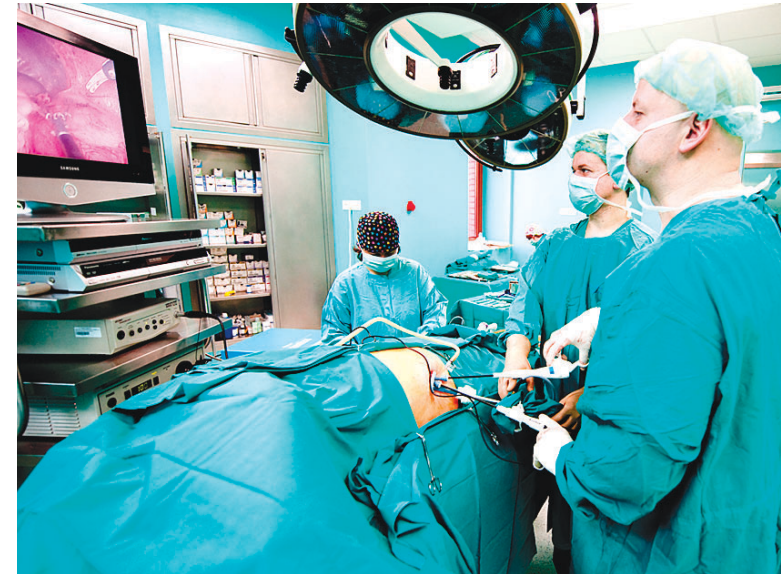

Figure 1. Left adrenalectomy by SILS method the patient is positioned on the right side, and the SILS port is placed in the umbilicus

its opening to the vena cava inferior and superior, middle and inferior suprarenal arteries were catered for. After complete resection of the adrenal gland it was placed in the bag and removed through the opening in the umbilicus. The umbilical wound was closed with layer sutures.

\section{Results}

Total operative time from the incision to the skin closure varied between 70 and $150 \mathrm{~min}$. In one case introduction of two additional $5 \mathrm{~mm}$ trocars was necessary. It was caused by difficulties with support of the mobilized spleen, so that it would not fall into the operating field. In this particular case the operation time was the longest, reaching 150 min. During all the procedures, instruments with a flexible tip were used, mainly because of their increased length, although the bending option was rarely used. Total blood loss during the procedures varied between 10 and $20 \mathrm{ml}$. On the first postoperative day, in all patients, a control abdominal ultrasound scan was performed and in none of them was free fluid in the peritoneal cavity confirmed. Patients were cardiopulmonary competent and no episodes of blood pressure drop were observed. Virtually no pain episodes were reported. Oral alimentation was introduced on the first postoperative day. Hospital stay following surgery averaged 1.7 days (2 patients left hospital on the first postoperative day, the remaining patients on the second day). There were no distant or local complications observed in the postoperative period.

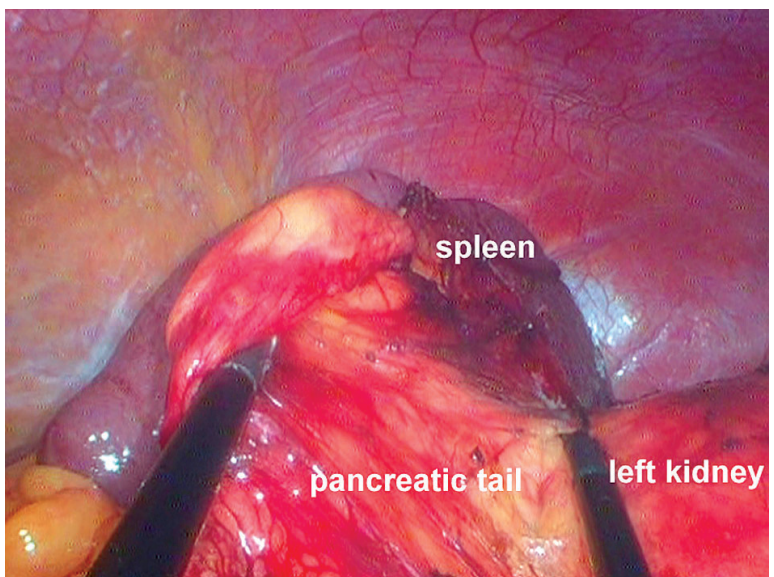

Figure 2. Intraoperative view - left adrenalectomy by SILS method - mobilization of spleen and pancreatic tail

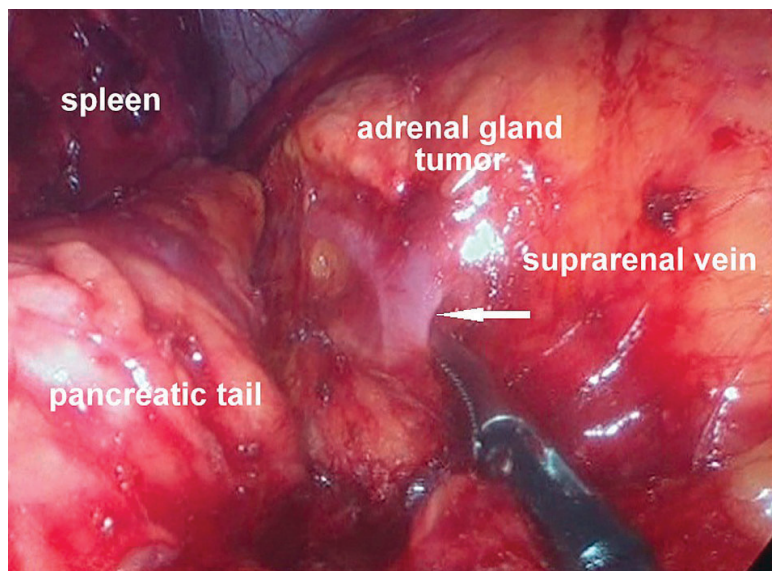

Figure 3. Intraoperative view - left adrenalectomy by SILS method - dissection free of the left suprarenal vein and its preparation for clipping

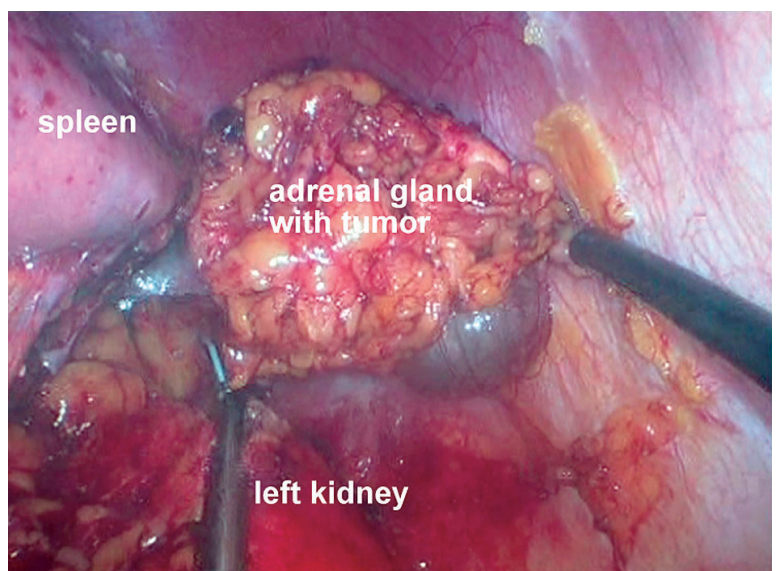

Figure 4. Intraoperative view - left adrenalectomy by SILS method - adrenal gland dissected from the surrounding tissues 


\section{Discussion}

Two outstanding surgeons, who performed the first successful adrenalectomies independently of each other in a short time interval, in 1927, are recognized as the pioneers of adrenal surgery [44]. They were: Cesar Roux, professor at the University of Lausanne, the most remarkable student of Theodor Kocher; and Charles Horace Mayo, one of the founders of Mayo Clinic in Rochester, who only a few months later performed the first adrenalectomy in the USA for adrenal pheochromocytoma [14, 15]. Open adrenal surgery was the gold standard for almost 70 years, and the technique of the procedure was only slightly modified over this period of time. Along with the development of laparoscopic surgery, adrenal surgery changed. The Canadian Michel Gagner performed laparoscopic adrenalectomy for the first time in 1992 [16]. This procedure was very well received by endocrinology surgeons and undeniably revolutionized the approach towards operations on patients with adrenal gland pathology. This technique led to the improvement of treatment outcomes, decreased the percentage of complications and thereby allowed faster patient recovery following surgery. Endoscopic surgery using access through the natural body orifices, one of which, according to some authors, is the umbilicus (natural orifice transluminal endoscopic surgery - NOTES), since the beginning of the $21^{\text {st }}$ century has constituted a dynamically evolving branch of surgery. Procedures using the umbilicus as the peritoneal cavity access were first described in 1999, and the organ that focused attention on its use was the gallbladder [17, 18]. Until now, there has been no uniform nomenclature for operations performed with this technique. Hence, in the literature one can come across many terms for the same technique [11, 12, 19]. In the past 10 years there has been substantial progress in the technique, and worldwide apart from cholecystectomy also information on successful appendectomy appeared [20]. Moreover, single reports on splenectomy performed with this technique, large bowel resections, nephrectomy, bariatric procedures or inguinal hernioplasty can be found [19, 21-24]. In 1996, a German surgical team led by Martin Waltz performed the first laparoscopic adrenalectomy via one incision from a retroperitoneal approach (single access retroperitoneoscopic adrenalectomy - SARA) $[25,26]$. During the manuscript preparation only a few publi- cations on adrenalectomy performed by the SILS method via transperitoneal access appeared [27]. Operations using the new method are frequently considered to be a challenge for the operative team. Performing a cholecystectomy was the first step to learn how to operate on the adrenal glands using SILS. The relatively short learning curve of this operation as well as good results persuaded us to attempt laparoscopic adrenalectomy with this technique [28]. In our centre, we prefer laparoscopic adrenalectomy performed via lateral transperitoneal access, which is the most commonly used access in adrenal gland surgery worldwide, and the performed SILS operation can be seen as a development of this method. In 2006, Gumbs and Gagner presented an analysis were they took into account 19 reports regarding laparoscopic adrenalectomies, having included at least 100 patients (2565 patients in total). In $70 \%$ of cases adrenalectomy from the lateral transperitoneal approach was the method of choice, in $20 \%$ adrenalectomy from the retroperitoneal approach was performed, and in 10\% from the anterior transperitoneal approach [35]. We performed our first laparoscopic adrenalectomies in 2003. Since then 250 such operations have been performed [29-34]. Broad experience in the "classic" laparoscopic adrenalectomy was undoubtedly a substantial factor allowing for the shortening of the learning curve of the new operative technique. Despite the fact that individual steps of the operation were similar to the procedures using a higher number of trocars, we noticed several differences in the SILS method consequent to the arrangement of working instruments. Relatively short patients were qualified for surgery. It becomes of our concern if the laparoscope and instruments introduced through the umbilicus would allow free and easy preparation in the diaphragm proximity. Additionally, we started operations by the SILS method with the tumour of the left adrenal cortex because of the anatomical relations (presence of liver) on the right side, which undeniably constitutes a factor impeding operation. It is also important to point out the quite important fact that there is different tissue retraction in operations via the SILS technique, which can cause some difficulties at the beginning of learning the method. Time of the described operations varied between 70 and $150 \mathrm{~min}$ (in a patient who required insertion of additional trocars) - mean $104 \mathrm{~min}$. This is comparable with our observations regarding "classic" laparoscopic adrenalectomy. 
Mancini et al. quotes that the mean operative time for the operation with lateral transperitoneal access is $130 \mathrm{~min}$ [36]. Henry et al. (146 min) and Otto et al. (149 min) [37, 2] achieved similar results. A far longer mean operative time is quoted by Guazzoni et al. (160 min) [38]. During the SILS adrenalectomy we recorded 10 to $20 \mathrm{ml}$ blood loss. Porpiglia et al. reports that it was around $100 \mathrm{ml}$ [39]. Both analysed parameters (mean time and blood loss during the surgery) are slightly lower than in the other authors' reports, concerning classic laparoscopic adrenalectomy via lateral transperitoneal access.

Tsimoyiannis presented a study comparing the analgesic requirement in subjects in whom "classic" laparoscopic cholecystectomy and the SILS procedure were performed, concluding that their use was significantly lower for patients who underwent SILS [9]. To date there are no reports on this problem in the case of adrenalectomy. However, we noticed that patients treated by the SILS method reported less pain and lower need for analgesics. Also, it appears that they better tolerated the postoperative period and mobilization. Nevertheless, for the time being, these are only subjective observations that require verification by comparisons in a larger group of patients.

\section{Conclusions}

The presented procedures of SILS adrenalectomy via transperitoneal access, to our knowledge, are among the first in Poland. These operations are feasible and in selected cases might provide a favourable course. Perfect knowledge of the laparoscopic technique and experience in both laparoscopic adrenal gland operations and transumbilical single incision operations allows for safe patient selection. In case of technical difficulties, conversion to "classic" laparoscopy and completion of the procedure is possible. Initial experience permits the conclusion that the SILS operation brings a better cosmetic effect. Evaluation of the number and the nature of complications as well as distant results of the adrenal gland tumour treatment would be possible following analysis on a larger group of patients.

\section{References}

1. Gagner M, Lacroix A, Prinz R, et al. Early experience with laparo scopic approach for adrenalectomy. Surgery 1993; 114: 1120-4.

2. Otto M, Dzwonkowski J, Ciąćka T. Adrenalektomia laparoskopowa u chorych w podeszłym wieku. Wideochirurgia 2006; 2: 54-8.
3. Imai T, Kikumori T, Ohiwa M, et al. A case-controlled study of laparoscopic compared with open lateral adrenalectomy. Am J Surg 1999; 178: 50-3.

4. Prinz R. A comparison of laparoscopic and open adrenalectomies. Arch Surg 1995; 130: 489-92.

5. Thompson G, Grant C, van Heerden J, et al. Laparoscopic versus open posterior adrenalectomy: a case-control study of 100 patients. Surgery 1997; 122: 1132-6.

6. Dudley N, Harrison B, Comparison of open posterior versus transperitoneal laparoscopic adrenalectomy. Br J Surg 1999; 86 : 656-60.

7. Brunt L, Doherty G, Norton, et al. Laparoscopic adrenalectomy compared to open adrenalectomy for benign adrenal neoplasms. J Am Coll Surg 1996; 183: 1-10.

8. Kurpiewski W, Pesta W, Kowalczyk M, et al. SILS cholecystectomy - our first experiences. Wideochirurgia 2009; 4: 91-4.

9. Tsimoyiannis E, Tsimogiannis K, Pappas-Gogos G, et al. Different pain scores in single transumbilical incision laparoscopic cholecystectomy versus classic laparoscopic cholecystectomy: a randomized controlled trial. Surg Endosc 2010; 24: 1842-8.

10. Hernandez J, Morton CA, Ross S, et al. Laparoendoscopic single site cholecystectomy: the first 100 patients. Am Surg 2009; 75: 681-5.

11. Bucher P, Pugin F, Buchs N, et al. Single port access laparoscopic cholecystectomy (with video). World J Surg 2009; 33: 1015-.9

12. Edwards C, Bradshaw A, Ahearne P, et al. Single-incision laparoscopic cholecystectomy is feasible: initial experience with 80 cases. Surg Endosc 2010 Mar 3. [Epub ahead of print]

13. Toutonch S, Cieśla, Krajewska E, et al. Wyłuszczenie laparoskopowe pojedynczego guza nadnercza u pacjentki z pierwotnym hiperaldosteronizmem. Wideochirurgia 2007; 2: 164-7.

14. von der Mühl R. Contribution à l'étude des paragangliomes. Thesis, L'Université de Lausanne, Lozanna, 1928: 32.

15. Mayo C. Paroxysmal hypertension with tumour of retroperitoneal nerve. JAMA 1927; 89: 1047-50.

16. Gagner M, Lacroix A, Bolte E. Laparoscopic adrenalectomy in Cushing's syndrome and phaeochromocytoma. N Engl J Med 1992; 327: 1033.

17. Bresadola F, Pasqualucci A, Donini A, et al. Elective transumbilical compared with standard laparoscopic cholecystectomy. Eur J Surg 1999; 165: 29-34.

18. Piskun G, Rajpal S. Transumbilical laparoscopic cholecystectomy utilizes no incisions outside the umbilicus. J Laparoendosc Adv Surg Tech A 1999; 9: 361-4.

19. Michalik M, Orłowski M, Frask A, et al. LESS (laparo-endoscopic single-site surgery) right hemicolectomy. Wideochirurgia 2009; 4: 164-7.

20. Saber A, Elgamal M, El-Ghazaly T, et al. Simple technique for single incision transumbilical laparoscopic appendectomy. Int J Surg 2010; 8: 128-30.

21. Śmietański M, Kitowski J, Tarasiuk D. Laparoscopic abdominal hernia repair with SILS port - our first experiences. Wideochirurgia 2009; 4: 76-8.

22. Targarona E, Pallares J, Balague C, et al. Single incision approach for splenic diseases: a preliminary report on a series of 8 cases. Surg Endosc 2010 Feb 23. [Epub ahead of print] 
23. Reavis K, Hinojosa M, Smith B, et al. Single-laparoscopic incision transabdominal surgery sleeve gastrectomy. Obes Surg 2008; 18; $1492-4$.

24. Rane A, Rao P, Bonadio F, et al. Single port laparoscopic nephrectomy using anovel laparoscopic port (R-port) and evolu- tion of single laparoscopic port procedure (SLIPP). J Endourol 2007; 21: 287.

25. Walz M, Peitgen K, Hoermann R, et al. Posterior retroperitoneoscopy as a new minimally invasive approach for adrenalectomy: results of 30 adrenalectomies in 27 patients. World J Surg 1996; 20: 769-74.

26. Waltz M, Alesina P. Single access retroperitoneoscopic adrenalectomy (SARA) - one step beyond in endocrine surgery. Lang Arch Surg 2009; 394: 447-50.

27. Castellucci S, Curcillo P, Ginsberg P, et al. Single port access adrenalectomy. J Endourol 2008; 22: 1573-6.

28. Kravetz A, Iddings, Basson M, et al. The learning curve with single-port cholecystectomy. JSLS 2009; 13: 332-6.

29. Budzyński A, Rembiasz K, Migaczewski M, et al. Operacje złośliwych nowotworów nadnerczy techniką laparoskopową z dostępu przezotrzewnowego. Pol Przegl Chir 2009; 81: 1092-108.

30. Budzyński A. Wycięcie nadnercza techniką laparoskopową. Medycyna Praktyczna 2006; 06: 95-112.

31. Budzyński A, Rembiasz K, Bobrzyński A, et al. Laparoskopowa adrenalektomia $z$ dostępu przezotrzewnowego. Wideochirurgia 2005; 10: 53-7.

32. Gołkowski F, Jabrocka-Hybel A, Budzyński A, et al. Diagnostyka przedoperacyjna u chorych z guzami nadnerczy. Folia Med Crac 2005; 45: 89-97.

33. Budzyński A, Huszno B, Rembiasz K, et al. Przezotrzewnowa laparoskopowa adrenalektomia w leczeniu hormonalnie czynnych i niemych guzów nadnerczy. Pol Przegl Chir 2005; 77: 1161-71.

34. Budzyński A, Bobrzyński A, Budzyński P. Minimalnie inwazyjna chirurgia endokrynologiczna. Przegl Lek 2002; 59: 950-4.

35. Gumbs A, Gagner M. Laparoscopic adrenalectomy. Best Pract Res Clin Endocrinol Metab 2006; 20: 483-99.

36. Mancini F, Mutter D, Peix J, et al. Experiences with adrenalectomy in 1997. Apropos of 247 cases. A multicenter prospective study of the French-speaking Association of Endocrine Surgery. Chirurgie 1999; 124: 368-74.

37. Henry J, Defechereux T, Raffaelli M, et al. Complications of laparoscopic adrenalectomy: results of 169 consecutive procedures. World J Surg 2000; 24: 1342-6.

38. Guazzoni G, Cestari A, Montorsi F, et al. Eight-year experience with transperitoneal laparoscopic adrenal surgery. J Urol 2001; 166: 820-4

39. Porpiglia F, Destefanis P, Fiori C, et al. Does adrenal mass size really affect safety and effectiveness of laparoscopic adrenalectomy? Urology 2002; 60: 801-5. 